\title{
The image of regional government in the context of digital transformations and networked political technologies (on the example of Kuzbass)
}

\author{
Yaroslav Nekrasov ${ }^{1}$, Izolda Sakhvadze ${ }^{2}$, and Sergey Chirun ${ }^{1, *}$ \\ ${ }^{1}$ Kemerovo State University, Krasnaya Str., 6, 650000 Kemerovo, Russia \\ ${ }^{2}$ Siberian State University of Railways, Dusi Kovalchuk Str., 191, 630049 Novosibirsk, Russia
}

\begin{abstract}
The presented article is devoted to the problems of technologizing the image of the regional head of the executive branch of government in the context of the massive use of new political technologies. The purpose of our study was to form an idea of the current needs of civil society for the political image of the head of the Russian region (using the example of the Kemerovo region), as well as to form an idea of modern network technologies used while creating the image of regional government institutions. In the study, based on the main methodological provisions of neoinstitutionalism, we used quantitative and qualitative methods of political analysis. Including this: intent-analysis; network analysis; sampling method based on stratified sampling; method of questionnaire survey of residents of the Kemerovo region - 823 respondents; correlation analysis in the SPSS system of questionnaires of the respondents we interviewed; expert survey. During the study, we revealed the main elements in the structure of the image of the governor of Kuzbass S.E. Tsivilev. Our research allows us to assert that at the moment the image of the governor of Kuzbass S.E. Tsivilev needs serious correction and optimization. Such optimization can be effectively implemented through using of networked political technologies.
\end{abstract}

\section{Introduction}

In political science, the image can be interpreted as the purposeful construction of the image of a politician to gain the trust of the population, using various political technologies, analyzing the political situation, considering the personal characteristics of the political actor and the peculiarities of the psychology of the local population.

The political science approach has developed its own terminology for the types of image. In line with it, the image of a politician can be subdivided into objective, subjective and ideal.

An objective image is how voters evaluate a candidate, what impression it makes. Subjective image - the idea of a candidate about himself, and what impression he makes on

\footnotetext{
* Corresponding author: author@email.org
} 
the electorate. An ideal image is the image that voters would like to see in a candidate.

These characteristics directly depend on the socio-value orientations of society, formed through history, culture and traditions. An ideal image appears as a set of such personal characteristics of a candidate that fully meet the needs of a specific pre-election situation.

Self-image is experience, habits, skills, education and everything that forms a personality in a political actor and reflects its state. Self-image is an image at the psychological level (behavioral approach). The perceived image is the assessment of a candidate or current politician by his close circle and the electorate. This evaluation may not coincide with assessing the politician himself. The image is perceived by the environment and voters through filters, depending on value and social guidelines [1]. Politicians often do not know how they really are treated, therefore, focus groups and questionnaires of the population are used.

Also, in political science, a comparative image is used. In the context of this image, the image characteristics of two or more candidates are compared, thereby empirically identifying the weak and strong sides of both the candidate and his opponents. This type of image is favorable for specialists in the field of PR technologies. Seeing the differences between candidates, you can adjust the PR campaign in one way or another.

Many scientific disciplines and branches of scientific knowledge are involved in the formation of the image, such as economics, psychology, marketing, public relations, political science. The main technologies of image formation include: management technologies; electoral technologies, imageology; Information Technology; PR technologies (public relations); political consulting. It should be noted that at the present stage there are a lot of political technologies. In the context of accelerated digitalization and globalization of social and political processes, PR technologies are acquiring a new round of development [2]. PR technologies are a system for studying various social trends, analyzing public opinion to ensure the implementation of political goals.

The field of public relations is directly related to the controlled impact on the public.

At the present stage, the implementation of PR technologies has significantly accelerated. In a networked society, most of the tasks set by political technologists are solved through SMM and other digital technologies on the Internet [3].

Many political technologies consider digital technologies as the most effective political technologies. The speed of feedback, the growing influence of the Internet in the political process, even raises doubts about the effectiveness of traditional political technologies [4].

Let's name a number of the most popular and frequently used digital political technologies by political scientists. Sending campaign material by e-mail or on personal pages on social networks. Creation of sites, creation of accounts on social networks, as well as the creation of sites by opponents to «tarnish» the reputation of the antagonist candidate [5].

Conducting Internet conferences, media forums through Internet broadcasting. Astroturfing is a technology for creating artificial public opinion in order to exert pressure on the ruling elite.

Sockpuppeting technology is artificially whipping up a stir on the Internet by using Internet bots or clones [6]. This technology is realized through the use of special software capable of automatically generating thousands of «fake» accounts, which are then used to influence information on Internet users.

Quite often, «Sockpuppeting» is created by professional Internet trolls to artificially whip up the majority effect. Bot programs are almost impossible to distinguish from real Internet users, as they are often tied to «fake addresses». As a rule, bots are created to generate likes, they are also able to create hype around a politician, maintain interest in a specific topic, and help spread and replicate the post-truth attributes of Internet memes [7]. This, in particular, is implemented through fake accounts of opinion leaders on social 
networks [8].

\section{Materials and Methods}

The purpose of our study was to form an idea of the current needs of civil society for the political image of the head of the Russian region (using the example of the Kemerovo region), as well as to form an idea of modern network technologies used in the process of creating the image of the leading institutions of regional power.

Research objectives: to identify the most important technologies for the formation and promotion of the political image in the context of the digitalization of society; to identify the main features of network forms of political participation; to present the dynamics of the image of the governor of Kuzbass in the modern communicative space.

Our research is based on the methodology of poststructuralism and neoinstitutionalism. As a basis for the intent-analysis of the speech image S.Ye. Tsivilev, we have selected a press conference «Strategy 2035», as well as several reporting press conferences of the Governor of Kuzbass.

The activities of the governor involve many different public speeches, as well as work with the population, but mainly it concerns the solution of local problems, while large press conferences cover more different issues.

During such press conferences, not only an idea of politics is formed, but also of a person.

The press conferences we have chosen are directly related to the activities of the governor, suggest an official style of rhetoric, but do not exclude «lyrical» digressions either. In the course of analyzing the verbal communication style of the governor of Kuzbass, we identified the main features of S.E. Tsivileva.

In the process of conducting applied research, we used: content analysis of references to the activities of the governor of Kuzbass in social networks; sampling method based on stratified sampling; method of questionnaire survey of residents of the Kemerovo region 823 respondents; correlation analysis in the SPSS system of questionnaires of the respondents we interviewed; expert survey of professors of Kemerovo State University specializing in the problems of political regional studies; secondary analysis of research results on the use of SMM technologies.

Our research was carried out by employees and graduate students of Kemerovo State University and the Siberian Institute of Social and Political Research.

\section{Results and Discussion}

The governor's image is formed through using certain political technologies, but it should be noted that not all political technologies can be used to form and broadcast the image to the masses.

It seems to us possible to analyze the image of the governor S. E. Tsivilev in line with the three-stage model of image formation, which includes a number of important elements.

1. Development of personal characteristics:

Verbal communication style. The leading way of Tsivilev's speech influence is rapprochement with the people, and the main communicative tactic is cooperation. Note that the tactics of cooperation is necessary when there is a request for the integration of various positions in solving urgent problems.

In practice, this tactic is implemented through using possessive pronouns such as «our», «we», «together». For example, "We have created a serious reserve of money to solve the problems of Kuzbass» - a quote from S. E. Tsivilev. 
This tactic helps to reduce the distance between the government and society, thanks to it, «alienation of power» is overcome, and a positive image of the regional government is formed.

Also, the tactics of speech impact of the problem-solution was used, for example: «We knew that such a question would follow, so we prepared for ..., but what we are doing for this ...».

Many of the governor's answers to questions were structured in this way. This tactic of speech influence assesses the governor through the prism of understanding the problems and ways to solve them. However, this technology may have certain risks, since any deviation from the position of a problem-solution can negatively affect the image of the governor and even create an anti-rating for him.

For example, some social programs operating under the former governor - A. M. Tuleyev, under S. E. Tsivilev were abolished, which in turn negatively affected the rating of the governor of Kuzbass.

Another example, S. E. Tsivilev uses the tactics of influencing the audience through the demonstration of personal experience: «I personally have been to Taiga several times, we went and looked at the treatment facilities, watched where this water was flowing from...». Or else: «I personally was in this boiler house, it's impossible to work there, then I coughed for two more days...». This method of speech influence contributes to the formation of the politician's image, included in the activities and life of the region, which in turn also contributes to a positive perception of the governor's image.

The governor used the tactics of revealing personal qualities: «In my family, no one smokes, does not drink alcohol, we lead an active lifestyle ...»-S. E. Tsivilev.

This tactic builds an attitude towards politics through the prism of personal characteristics, helps to reduce the distance between the politician and the people.

2. Non-verbal communication style. The analysis of non-verbal communication involves the consideration of kinesics, takesics, proxemics, prosody and extralinguistics. We will focus our attention on kinesics, prosodics and extralinguistics, since the remaining two methods of non-verbal communication can be studied in detail only through direct contact with the object of analysis. Within the framework of kinesics, postures, gestures, facial expressions and gait, passages and extralinguistics, intonation, volume, and timbre of the voice are considered. As an empirical base, we used the press conferences mentioned earlier, as well as the image clips «S. E. Tsivilev about life, about love and about yourself», short videos covering the activities of the governor, such as: «Kuzbass $=$ Kemerovo region», etc.

In the course of analyzing the non-verbal communication style, we identified the following: in the poses of S. E. Tsivilev, closeness prevails, this is evidenced by the combined palms, as well as the position of the «schoolboy» hands on the table, this may also indicate a strong emotional stress. In turn, the gestures are quite calm and smooth, basically this could be observed within the framework of the press conference closer to the middle, since the tension subsides, the person manages to adapt to the situation, the facial expressions are mostly calm and not expressed, you can rarely see the governor's face smile, the gait is calm, not sweeping. Loudness, intonation and timbre are calm. All of the above speaks of restraint, self-control, first of all, in our opinion, this is associated with the military bearing of S. E. Tsivilev.

In the biography of S. E. Tsivilev is revealed as a team player, a patriot, a man of honor, executive and obligatory. All this in one way or another relates to military service, which Tsivilev gave 16 years, which corresponds to the needs of the Russian society, in which, according to research, the values of «militant patriotism» have significantly intensified in recent years [9]. Tsivilev is also shown in his biography as a person competent in the coal mining industry, which is relevant for Kuzbass. 
Creation of an image of a politician capable of solving the most pressing social problems. While still at the post of Acting Governor S. E. Tsivilev at the first forum announced that the site sergeytsivilev.ru was created. He also suggested sending messages to Kuzbass people with video and photo reports on the condition of the roads.

Priority areas of activity were: the problem of dilapidated housing, health care, road conditions, ecology, construction of new schools and education. These problems were taken into account in the preparation of the «S trategy 2035», as S. E. Tsivilev himself asserts.

The political situation in Kuzbass is largely determined by the remnants of the legacy of the former governor A. M. Tuleyev, who ruled the region for 20 years. The long authoritarian rule of A. M. Tuleyev, the formation of a clan system of state power by him in the region, according to a number of political scientists, had an extremely negative impact on the situation in the region [10]. It is no coincidence that researchers of regional political regimes classify the Kemerovo region as a region with a sultanist political regime; they also focus on establishing the patron-client network relations between business and government. For example, Yu. N. Blagoveshchensky and G. A. Satarov try to interpret the cluster structure of networks, which, in their opinion, is associated with the structure of network nodes [11].

S. E. Tsivilev, as the researchers note, initially looked advantageous against the background of the former governor. In recent years, the reign of A. M. Tuleyev cannot be called successful, first of all, in our opinion, this is due to A. M. Tuleyev's protracted illness, his actual absence in the region, distance from the problems of the population and a number of high-profile corruption scandals associated with his closest environment.

But if the first one leaves a negative imprint on the formation of S.E. Tsivilev's image, although it stimulated his team to look for and find new network mechanisms of interaction between business and government, then the second circumstance, according to the researchers, was used to form a positive image, which in turn reflected in the creation of accounts on social networks and personal visits to remote territories of Kuzbass (image of openness for the people) [12]. S. E. Tsivilev comes from the environment of big business, and even earlier - comes from the environment of the military. And as V. M. Barsegyan notes, although «positions in law enforcement agencies and positions in business do not provide direct access to the governor's office, however, the experience of working in these structures, as well as the experience of the municipal service, is an important characteristic of the heads of regions» [13].

Professor A.S. Akhremenko draws attention to the fact that network connections between the digitalization of the online environment are related to connections in physical reality, and their structure can influence political behavior, and «digital platforms can act as central platforms for the formulation of collective goals and identities» [14]. Political scientists also discuss the meaningful differences between communication processes in online and offline spaces. The existing problems in the Kemerovo region demanded and still require the solution of problems in such spheres as ecology, problems of entrepreneurship in general, outflow of the population, housing and communal problems, dilapidated housing, education and medicine, which is in a catastrophic situation in the region and requires a wide public discussion, including with the participation of the governor. However, as the researchers note, there is an excessive formality in the publications on behalf of the governor. Whereas «the specificity of social networks is aimed at revealing personal characteristics» [12].

\section{Conclusion}


The Kemerovo Region is a densely populated area, which includes 16 urban districts, 18 municipal districts, 22 urban and 154 rural settlements, which in turn also imposes regional specificity on the formation of the governor's image.

The directions of activity should concern not only the cities of Kemerovo and Novokuznetsk, but also extend to other territorial associations. In turn, it should be noted that work in many territorial associations is being carried out, but little coverage in the media and on personal pages in social media of S. E. Tsivilev. The coverage of the governor's activities should be complete, to the greatest extent it should be told about working trips to various cities of Kuzbass.

We analyzed the image of the governor of Kuzbass in accordance with a three-stage model of image formation, and also tried to assess the effectiveness of using certain political technologies in creating a positive image of the governor of Kuzbass. In the course of the analysis, we found that despite the use of almost all popular political technologies in the formation of the image of S. E. Tsivilev, it is too early to say that his image is fully formed.

Based on our research, a lot of practical recommendations were formulated to improve the image of the Governor of Kuzbass S.E. Tsivilev. At the same time, we conditionally divided the recommendations into two categories. Recommendations of the first order, which include: the use of communicative tactics «understanding the urgency of the problem; consideration of the issue - decision»; promotion, positioning of ideas; directions of activity and worldviews of the politician.

However, despite the urgent need to form a comprehensive and positive image of the regional authorities, we are forced to state the fact that at the moment the image of the Governor of Kuzbass S. E. Tsivilev has not been formed. This fact is due to a complex of reasons such as the difficult socio-economic situation in the region; political specificity, consisting in the establishment of patron-client relations; increasing the distance between the population of the region and the elites; lack of civil society institutions in the region. All of the above reasons actualize the problem of correcting and optimizing the image of regional authorities in Kuzbass, based on an analysis of using various political technologies and a subsequent analysis of their success.

\section{References}

1. S.V. Biryukov, M. M. Kislyakov, S. N. Chirun, Bulletin of Tomsk State University, 50, 168 (2019)

2. R.V. Petukhov. Policy. Political Studies, 6, 103 (2020)

3. J. Bisbee, J. M. Larson, American Political Science Review, 111 (3), 502 (2017)

4. I. S. Grigoriev, A. A. Dekalchuk, S. Sh. Gubaidullina, Policy. Political Studies, 1, 169 (2021)

5. A. D. Kazun, Policy. Political Studies, 1, 157 (2021)

6. D. S. Martyanov, POLITEX (Political Expertise), 1, 74 (2016)

7. A. G. Kostyrev, Policy. Political Studies, 2, 64 (2021)

8. S.V. Volodenkov, Yu. D. Artamonova, Bulletin of Tomsk State University, 53, 188 (2020)

9. Yu. P. Averin, Moscow State University Bulletin, 1, 85 (2021)

10. S. N. Chirun, Bulletin of Tomsk State University, 44, 253 (2018)

11. Yu. N. Blagoveshchensky, G. A. Satarov, Policy. Political Studies, 5, 96 (2019)

12. K.V. Vlasova, S. N. Chirun, Bulletin of the Kemerovo State University, 4, 176 (2019) 
13. V. M. Barsegyan, Policy. Political Studies, 4, 132 (2019)

14. A. S. Akhremenko, D. K. Stukal, A. P. Petrov, Policy. Political Studies, 2, 73 (2020) 